\title{
Front Matter: Volume 7417
}

, "Front Matter: Volume 7417," Proc. SPIE 7417, Organic Field-Effect Transistors VIII, 741701 (17 September 2009); doi: 10.1117/12.846118

SPIE Event: SPIE Photonic Devices + Applications, 2009, San Diego, California, SPIE. United States 


\title{
PROCEEDINGS OF SPIE
}

\section{Organic Field-Effect Transistors VIII}

\author{
Zhenan Bao \\ lain McCulloch \\ Editors
}

3-5 August 2009

San Diego, California, United States

Sponsored by

SPIE

Cosponsored by

Aldrich Chemistry (United States)

Corning Inc. (United States)

Solvay S.A. (Belgium)

Published by

SPIE 
The papers included in this volume were part of the technical conference cited on the cover and title page. Papers were selected and subject to review by the editors and conference program committee. Some conference presentations may not be available for publication. The papers published in these proceedings reflect the work and thoughts of the authors and are published herein as submitted. The publisher is not responsible for the validity of the information or for any outcomes resulting from reliance thereon.

Please use the following format to cite material from this book:

Author(s), "Title of Paper," in Organic Field-Effect Transistors VIII, edited by Zhenan Bao, lain McCulloch, Proceedings of SPIE Vol. 7417 (SPIE, Bellingham, WA, 2009) Article CID Number.

ISSN 0277-786X

ISBN 9780819477071

Published by

SPIE

P.O. Box 10, Bellingham, Washington 98227-0010 USA

Telephone +1 3606763290 (Pacific Time) · Fax +1 3606471445

SPIE.org

Copyright (c) 2009, Society of Photo-Optical Instrumentation Engineers

Copying of material in this book for internal or personal use, or for the internal or personal use of specific clients, beyond the fair use provisions granted by the U.S. Copyright Law is authorized by SPIE subject to payment of copying fees. The Transactional Reporting Service base fee for this volume is $\$ 18.00$ per article (or portion thereof), which should be paid directly to the Copyright Clearance Center (CCC), 222 Rosewood Drive, Danvers, MA 01923. Payment may also be made electronically through CCC Online at copyright.com. Other copying for republication, resale, advertising or promotion, or any form of systematic or multiple reproduction of any material in this book is prohibited except with permission in writing from the publisher. The CCC fee code is 0277-786X/09/\$18.00.

Printed in the United States of America.

Publication of record for individual papers is online in the SPIE Digital Library.

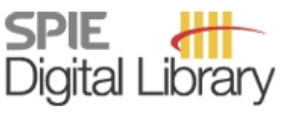

SPIEDigitalLibrary.org

Paper Numbering: Proceedings of SPIE follow an e-First publication model, with papers published first online and then in print and on CD-ROM. Papers are published as they are submitted and meet publication criteria. A unique, consistent, permanent citation identifier (CID) number is assigned to each article at the time of the first publication. Utilization of CIDs allows articles to be fully citable as soon they are published online, and connects the same identifier to all online, print, and electronic versions of the publication. SPIE uses a six-digit CID article numbering system in which:

- The first four digits correspond to the SPIE volume number.

- The last two digits indicate publication order within the volume using a Base 36 numbering system employing both numerals and letters. These two-number sets start with 00, 01, 02, 03, 04 , $05,06,07,08,09,0 A, 0 B \ldots$. OZ, followed by 10-1Z, 20-2Z, etc.

The CID number appears on each page of the manuscript. The complete citation is used on the first page, and an abbreviated version on subsequent pages. Numbers in the index correspond to the last two digits of the six-digit CID number. 


\section{Contents}

vii Conference Committee

ix WISE: the Wide-field Infrared Survey Explorer (Plenary Paper) [7419A-204]

E. L. Wright, Univ. of California, Los Angeles (United States)

MATERIALS I

741704 Conductors and semiconductors for advanced organic electronics [7417-02]

T. Meyer-Friedrichsen, A. Elschner, F. Keohan, W. Lövenich, H.C. Starck Clevios GmbH (Germany); S. A. Ponomarenko, N.S. Enikolopov Institute of Synthetic Polymeric Materials (Russian Federation)

741706 Triindole based single crystals and thin films for OLED and OFET applications [7417-04] E. M. García-Frutos, Consejo Superior de Investigaciones Científicas (Spain); C. Coya, Univ. Rey Juan Carlos (Spain); A. de Andrés, Consejo Superior de Investigaciones Científicas (Spain); R. Ramírez, Univ. Carlos III de Madrid (Spain); R. Ramírez, P. de Andrés, E. Gutierrez-Puebla, A. Monge, B. Gómez-Lor, Consejo Superior de Investigaciones Científicas (Spain)

741707 Herringbone structured thin films of alkyl-substituted pentacenes and FET performance (Invited Paper) [7417-05]

T. Minakata, Y. Natsume, K. Nagata, T. Saeki, H. Tateishi, M. Matsunaga, M. Tojo, Asahi-KASEl

Corp. (Japan); M. Yakiyama, Y. Naruta, Kyushu Univ. (Japan)

MATERIALS III

7417 OF Structure vs. property relationships in high mobility fused thiophene polymers (Invited Paper) [7417-13]

M. He, J. Li, M. L. Sorensen, F. Zhang, Corning Inc. (United States); H. H. Fong, V. A. Pozdin,

D. M. Smilgies, G. G. Malliaras, Cornell Univ. (United States)

$7417 \mathrm{OH}$ Performance and fabrication of organic field effect transistors with soluble oligomers [7417-15]

Y. Kitajima, J. Ru, T. Mizutani, K. Kojima, S. Ochiai, Aichi Institute of Technology (Japan)

7417 0l A crystalline alkylsilane dielectric surface-modification layer: a general strategy for high performance organic thin-film transistors (Best Student Paper Award) [7417-16]

A. Virkar, Stanford Univ. (United States); Y. Ito, Toppan Printing Co., Ltd. (Japan); S. Mannsfeld, M. Toney, Stanford Linear Accelerator Ctr. (United States); Z. Bao, Stanford Univ. (United States)

7417 0J Functionalized triindoles as a new class of $p$-type organic semiconductors [7417-17]

E. M. García-Frutos, B. Gómez-Lor, Consejo Superior de Investigaciones Científicas (Spain) 


\section{APPLICATIONS I}

7417 OU A flexible electrophoretic panel driven by organic TFTs (Invited Paper) [7417-29]

T.-S. Hu, Y.-K. Wang, Industrial Technology Research Institute (Taiwan)

7417 OW An flexible OLED driven by OTFT backplane manufactured using a scalable process (Invited Paper) [7417-31]

M. Katsuhara, I. Yagi, A. Yumoto, M. Noda, N. Hirai, R. Yasuda, T. Moriwaki, S. Ushikura,

A. Imaoka, T. Sasaoka, K. Nomoto, Sony Corp. (Japan)

\section{APPLICATIONS II}

741711 Solution processed low-voltage organic transistors based on self-assembled monolayer gate dielectrics [7417-36]

J. M. Ball, P. H. Wöbkenberg, F. Colléaux, J. Smith, D. D. C. Bradley, T. D. Anthopoulos, Imperial College London (United Kingdom)

741712 High-speed growth of pentacene thin films by in-line organic vapor phase deposition [7417-37]

C. Rolin, K. Vasseur, S. Steudel, P. Vicca, J. Genoe, P. Heremans, IMEC (Belgium)

\section{DEVICES II}

741718 Preparation of crystalline dielectric modification silane layer by spin-coating and its improvements on organic transistor performance [7417-43]

Y. Ito, Toppan Printing Co., Ltd. (Japan); A. Virkar, Stanford Univ. (United States); J. Locklin, Univ. of Georgia (United States); S. Mannsfeld, M. Toney, Stanford Synchrotron Radiation Lab. (United States); Z. Bao, Stanford Univ. (United States)

7417 1A Quasi one-dimensional transport in doped PBTTT and PBTTT thin film transistors [7417-45] J. D. Yuen, Univ. of California, Santa Barbara (United States); R. Menon, Univ. of California, Santa Barbara (United States) and Indian Institute of Science (India); N. E. Coates, E. B. Namdas, S. Cho, Univ. of California, Santa Barbara (United States); S. T. Hannahs, Florida State Univ. (United States); D. Moses, Univ. of California, Santa Barbara (United States); A. J. Heeger, Indian Institute of Science (India)

\section{POSTER SESSION}

$74171 \mathrm{C}$ Studies of organic complementary inverters with pentacene and PTCDI- $\mathrm{C}_{13} \mathrm{H}_{27}$ [7417-47] B.-L. Yeh, B.-Y. Sun, T.-H. Chou, Y.-H. Chen, J.-W. Lin, H.-L. Cheng, W.-Y. Chou, National Cheng Kung Univ. (Taiwan); H. J. H. Chen, National Chi Nan Univ. (Taiwan); F.-C. Tang, National Cheng Kung Univ. (Taiwan); B. Liou, National Applied Research Labs (Taiwan)

7417 ID Surface energy patterning for inkjet printing in device fabrication [7417-48]

J. Lin, P. Dahlsten, Åbo Akademi Univ. (Finland); J. Pekkanen, Tampere Univ. of Technology (Finland); M. Linden, Åbo Akademi Univ. (Finland); M. Mäntysalo, Tampere Univ. of Technology (Finland); R. Österbacka, Åbo Akademi Univ. (Finland) 
$7417 \mathrm{IF}$ The geometry effect on threshold voltage of top-contact and bottom contact pentacene based thin film transistors [7417-50]

Y.-W. Wang, D.-Z. Liu, M.-Y. Hong, National Changhua Univ. of Education (Taiwan);

H.-L. Cheng, National Cheng Kung Univ. (Taiwan)

Author Index 
Downloaded From: https://www.spiedigitallibrary.org/conference-proceedings-of-spie on 26 Apr 2023

Terms of Use: https://www.spiedigitallibrary.org/terms-of-use 


\title{
Conference Committee
}

\author{
Symposium Chair \\ Zakya H. Kafafi, National Science Foundation (United States) \\ Conference Chairs \\ Zhenan Bao, Stanford University (United States) \\ lain McCulloch, Imperial College London (United Kingdom) \\ Session Chairs \\ 1 Materials I \\ Antonio F. Facchetti, Polyera Corporation (United States) \\ 2 Materials II \\ Iain McCulloch, Imperial College London (United Kingdom) \\ 3 Materials III \\ Zhenan Bao, Stanford University (United States) \\ $4 \quad$ Fabrication and Characterization \\ Michael L. Chabinyc, University of California, Santa Barbara (United \\ States) \\ 5 Devices I \\ Stefan Mannsfeld, Stanford Linear Accelerator Center (United States) \\ 6 Applications I \\ Vitaly Podzorov, Rutgers University (United Kingdom) \\ $7 \quad$ Applications II \\ Gerwin H. Gelinck, TNO Science and Industry (Netherlands) \\ 8 Devices II \\ Alberto Salleo, Stanford University (United States)
}


Downloaded From: https://www.spiedigitallibrary.org/conference-proceedings-of-spie on 26 Apr 2023

Terms of Use: https://www.spiedigitallibrary.org/terms-of-use 